\title{
Technical adaptations of manual and rotary instruments for preparing a giant canine
}

\section{tooth}

\author{
Adaptações técnicas de instrumentos manuais e rotatórios para preparo de um dente canino \\ gigante
}

Adaptaciones técnicas de instrumentos manuales y rotatorios para la preparación de un canino gigante

Received: 06/21/2021 | Reviewed: 06/29/2021 | Accept: 07/02/2021 | Published: 07/14/2021

Geraldo Fernando Stroparo

ORCID: https://orcid.org/0000-0002-3563-9176 Private practice, Brazil

E-mail: jeferson.stroparo@gmail.com

Jeferson Luis de Oliveira Stroparo ORCID: https://orcid.org/0000-0003-1094-530X Universidade Positivo, Brazil

E-mail: jef_stroparo@hotmail.com

Paula de Moura

ORCID: https://orcid.org/0000-0003-3847-3025

Radiocenter Curitiba, Brazil

E-mail: paulademoura.radiocenter@gmail.com

Tatiana Miranda Deliberador

ORCID: https://orcid.org/0000-0003-4076-4905 Faculdade ILAPEO, Brazil

E-mail: tdeliberador@gmail.com

Allan Abuabara

ORCID: https://orcid.org/0000-0003-2454-3360

Healthcare Division of Joinville, Brazil

E-mail: allan.abuabara@gmail.com

Natanael Henrique Ribeiro Mattos

ORCID: https://orcid.org/0000-0003-2755-2270

Universidade Tuiuti do Paraná, Brazil

E-mail: natanael.mattos@utp.br

Camila Paiva Perin

ORCID: https://orcid.org/0000-0002-4646-8851

Universidade Tuiuti do Paraná, Brazil E-mail: camila.perin@utp.br

Marilisa Carneiro Leão Gabardo

ORCID: https://orcid.org/0000-0001-6832-8158 Universidade Positivo, Brasil

E-mail: marilisagabardo@gmail.com

Arissa Michelle Yamada Corrêa

ORCID: https://orcid.org/0000-0002-2771-4287

Universidade da Região de Joinville, Brazil

E-mail: arissayammada@gmail.com

Flares Baratto-Filho

ORCID: https://orcid.org/0000-0002-5649-7234

Universidade da Região de Joinville, Brasil

E-mail: fbaratto1@gmail.com

\begin{abstract}
Teeth with extraordinary length are a rare condition that complicates endodontic procedures due to the difficult in being reached the working length and making the adequate preparation of the root canal, once there are no endodontic instruments longer than $31 \mathrm{~mm}$ commercially available. This study presents a description of technical adaptations for endodontic preparation of a maxillary canine with $39.59 \mathrm{~mm}$ of length. The procedures adopted were based on the consultation of the literature regarding the treatment of long teeth, and included endodontic instrument adaptation and changing the reference point of the instrument. This study shows that extremely long teeth can be successfully instrumented endodontically using the described clinical techniques.
\end{abstract}

Keywords: Radiculomegaly; Root canal preparation; Canine tooth; Dental abnormalities. 


\begin{abstract}
Resumo
Dentes com comprimento extraordinário são uma condição rara que complica os procedimentos endodônticos pela dificuldade em se atingir o comprimento de trabalho e fazer o preparo adequado do canal radicular, uma vez que não há instrumentos endodônticos maiores que $31 \mathrm{~mm}$ disponíveis comercialmente. Este estudo apresenta uma descrição de adaptações técnicas para o preparo endodôntico de um canino superior com 39,59 mm de comprimento. Os procedimentos adotados basearam-se em consulta à literatura a respeito do tratamento de dentes longos, e incluíram adaptação do instrumento endodôntico e alteração do ponto de referência do instrumento. Este estudo mostra que dentes extremamente longos podem ser instrumentados endodonticamente com sucesso usando as técnicas clínicas descritas.
\end{abstract}

Palavras-chave: Radiculomegalia; Preparo do canal radicular; Dente canino; Anomalias dentárias.

\title{
Resumen
}

Los dientes con longitud extraordinaria son una condición poco común que complica los procedimientos de endodoncia debido a la dificultad para alcanzar la longitud de trabajo y realizar la preparación adecuada del conducto radicular, una vez que no existen instrumentos de endodoncia de más de $31 \mathrm{~mm}$ disponibles comercialmente. Este estudio presenta una descripción de las adaptaciones técnicas para la preparación endodóntica de un canino maxilar de 39,59 mm de longitud. Los procedimientos adoptados se basaron en la consulta de la literatura sobre el tratamiento de dientes largos, incluida la adaptación del instrumento endodóntico y el cambio del punto de referencia del instrumento. Este estudio muestra que los dientes extremadamente largos pueden instrumentarse endodónticamente con éxito utilizando las técnicas clínicas descritas.

Palabras clave: Radiculomegalia; Preparación del conducto radicular; Diente canino; Anomalías dentales.

\section{Introduction}

The knowledge of the root canal morphology and its variations is an indispensable prerequisite for the success of the root canal treatment (Vertucci, 2005). The internal anatomy of root canals often does not reproduce the simplicity of the external anatomy of the tooth (Pécora, Sousa Neto, \& Saquy, 1993). Canines teeth are not exception, and not always present an internal anatomy as simple as could be expected (Bolla \& Kavuri, 2011; Pécora et al., 1993; Somalinga Amardeep, Raghu, \& Natanasabapathy, 2014).

The maxillary canines exhibit the greatest combined crown plus root length in each arch and their root is very firmly anchored in alveolar bone. Because of the thick bony support and the length of the root, the canines are usually the most steadfast teeth in the mouth (Sajnani, 2015). The mean length of maxillary canine is $26.5 \mathrm{~mm}$, ranging from $20.0 \mathrm{~mm}$ to 32.0 mm (Burns \& Buchanan, 1994). However, studies have revealed the existence of extremely long canine, ranging from 41 to 52 mm in length (Booth, 1988; Hayward, 1980; Marashi \& Gorlin, 1990; Wilkie \& Chambers, 1990).

Treatment of dental anomalies is a potential endodontic challenge (Barletta, Grecca, Wagner, Ferreira, \& Lopez, 2010). Radiculomegaly is an anomaly that the teeth have extremely large roots, and it may be isolated (Al-Obaida, 2020; Wilkie \& Chambers, 1990) or correlated with other pathologies (Gorlin, Marashi, \& Obwegeser, 1996; Marashi \& Gorlin, 1990; Pace, Giuliani, \& Pagavino, 2011). In 1990, Marashi and Gorlin related radiculomegaly of canines with congenital cataracts. Gorlin et al. (1996), described the oculo-facial-cardio-dental (OFCD) Syndrome as a rare pathological condition characterized by ocular defects including microphthalmia and congenital cataract with secondary glaucoma and cardiac anomalies including ventricular and atrial septal defects or mitral valve prolapse. According to the authors, the typical facial features include a long narrow face, a high nasal bridge, and a bifid nasal tip. The dental anomalies include radiculomegaly, oligodontia, root dilacerations, malocclusion, and delayed eruptions (Gorlin et al., 1996; Kato, Kushima e Kushima, 2018; Pace et al., 2011). Smith, Cohen, Bhattacharyya, Islam, \& Kashtwari (2018) reviewed the literature concerning the patients with radiculomegaly and OFCD syndrome, revealing that in only one study was confirmed a case of nonsyndromic/nonfamilial radiculomegaly until that moment.

Extraordinary length of the tooth complicates endodontic procedures due to the difficult of cleaning all root length (Barletta et al., 2010), because there are no endodontic instruments longer than $31 \mathrm{~mm}$ commercially available. Few studies 
and have investigated the root canal treatment of long teeth (Al-Dahman, Al-Hawwas, \& Al-Jebaly, 2017; Barletta et al., 2010; Bellizzi, 1982; Booth, 1988; Cardoso et al., 2019; Hussain \& Awooda, 2020; Maden, Savgat, \& Görgül, 2010; Pace et al., 2011; Vargo \& Hartwell, 1992; Venokur \& Fink, 1976; Zmener, 2003). Thus, this study presents technical report of root preparation of a long maxillary canine with $39.59 \mathrm{~mm}$ of length, with adaptations techniques that can be used to deal with these cases.

\section{Technical Report}

\subsection{Ethical aspects}

The Ethics Committee in Human Research approved this study (registration 4.316.701). An extremely long maxillary canine was found in the Dental School's teeth bank. No patient data was found.

\subsection{Root canal preparation}

The maxillary canine, using digital pachymeter (MTX 316119, Guarulhos, Brazil), measured 39.59 mm in major length (Figure 1A).

Conventional 2-D radiograph was taken (Figure 1B) and cone beam computed tomography (CBCT) images were acquired using PreXion 3D (PreXion, Sao Matteo, USA). The DICOM files were imported to the e-Vol DX (CDT Software, São José dos Campos, Brazil) and Woopir Tomo (WOOPI Software, Campinas, Brazil) for the reconstruction process (Figure 1C). Overview visualization of internal and external tooth structures are shown in the Figures 1D-1H. 
Research, Society and Development, v. 10, n. 8, e39710817416, 2021

(CC BY 4.0) | ISSN 2525-3409 | DOI: htttp://dx.doi.org/10.33448/rsd-v10i8.17416

Figure 1. (A) Maxillary canine with $39.59 \mathrm{~mm}$. (B) Conventional 2-D radiograph. (C-H) Cone beam computed tomography (CBCT) images.
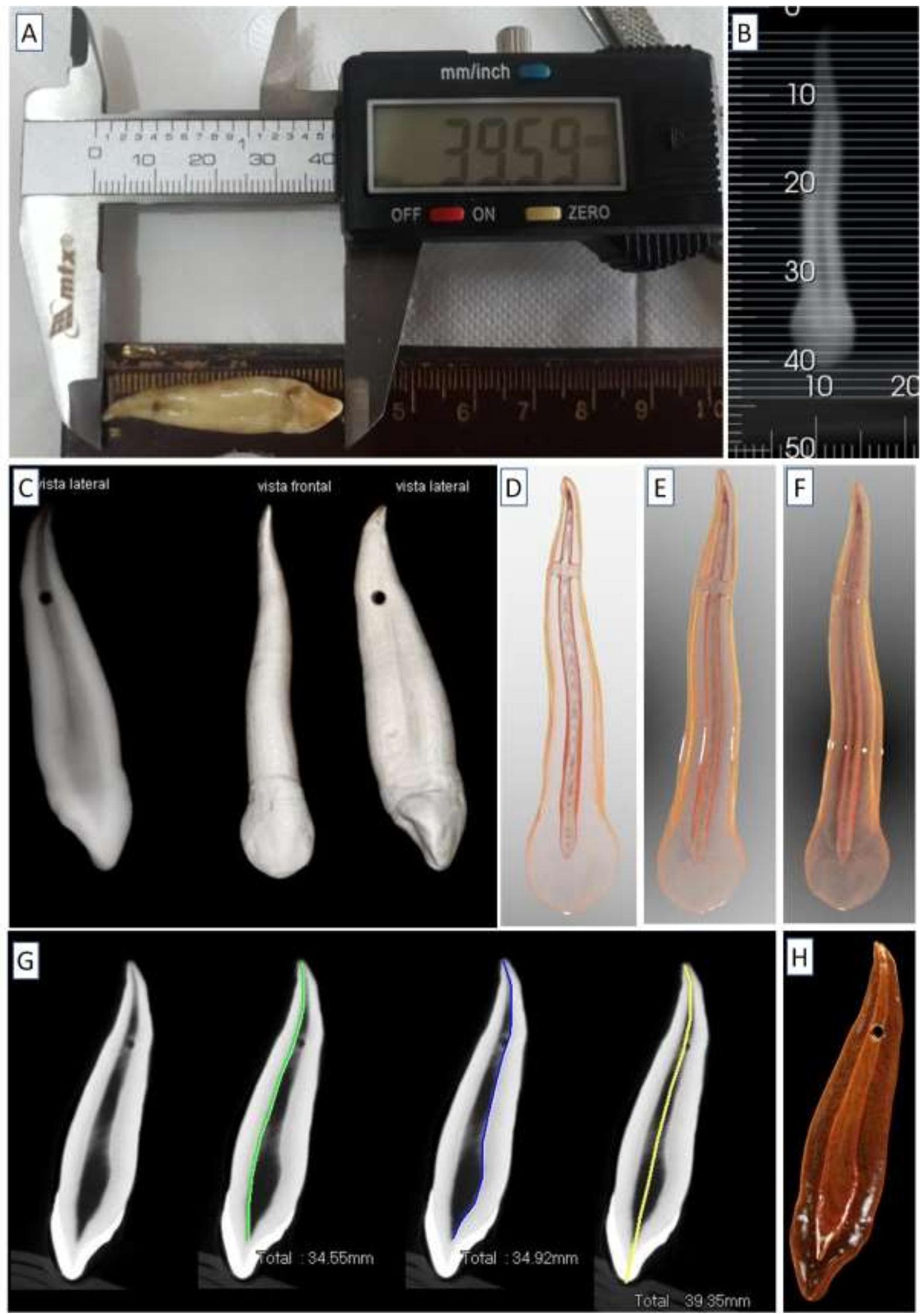

Source: Authors. 
Coronal access of the tooth was made through the palatal enamel at $2 \mathrm{~mm}$ from the cingulum, in incisal direction, with a round diamond bur 1014HL (KG Sorensen, Cotia, Brazil), creating divergent walls. The pulp chamber was irrigated with $2.5 \%$ sodium hypochlorite solution.

\section{Endodontic instrument adaptation}

A modification to the existing K-file \#15 of $31 \mathrm{~mm}$ length (TDK, Guangming, China) was made by cutting the inferior part of the plastic cable using conical-trunk diamond bur size 3080 (KG Sorensen, Cotia, Brazil) (Figure 2A). The file reached $35 \mathrm{~mm}$ length (Figure 2B). Also, a modification to the X1 rotary file of the X Rotary File System (TDK, Guangming, China) was made by cutting the inferior part of the handle using the conical-trunk diamond bur up to the level of its entry into the electric motor X-Smart ${ }^{\circledR}$ Plus (Dentsply Sirona, Ballaigues, Switzerland) (Figure 2C). The X1 file reached 33 mm length (Figure 2D).

Radiographic measurement showed that the original and modified endodontic instruments (hand and rotary files) did not reach the canal length (Figures 2E-2L). 
Figure 2. (A) Modification to the hand file of $31 \mathrm{~mm}$ length. (B) Hand file with $35 \mathrm{~mm}$ length. (C) Modification to the rotary file. (D) Rotary file with $33 \mathrm{~mm}$ length. (E-L) Radiographic measurement with original and modified endodontic instruments.
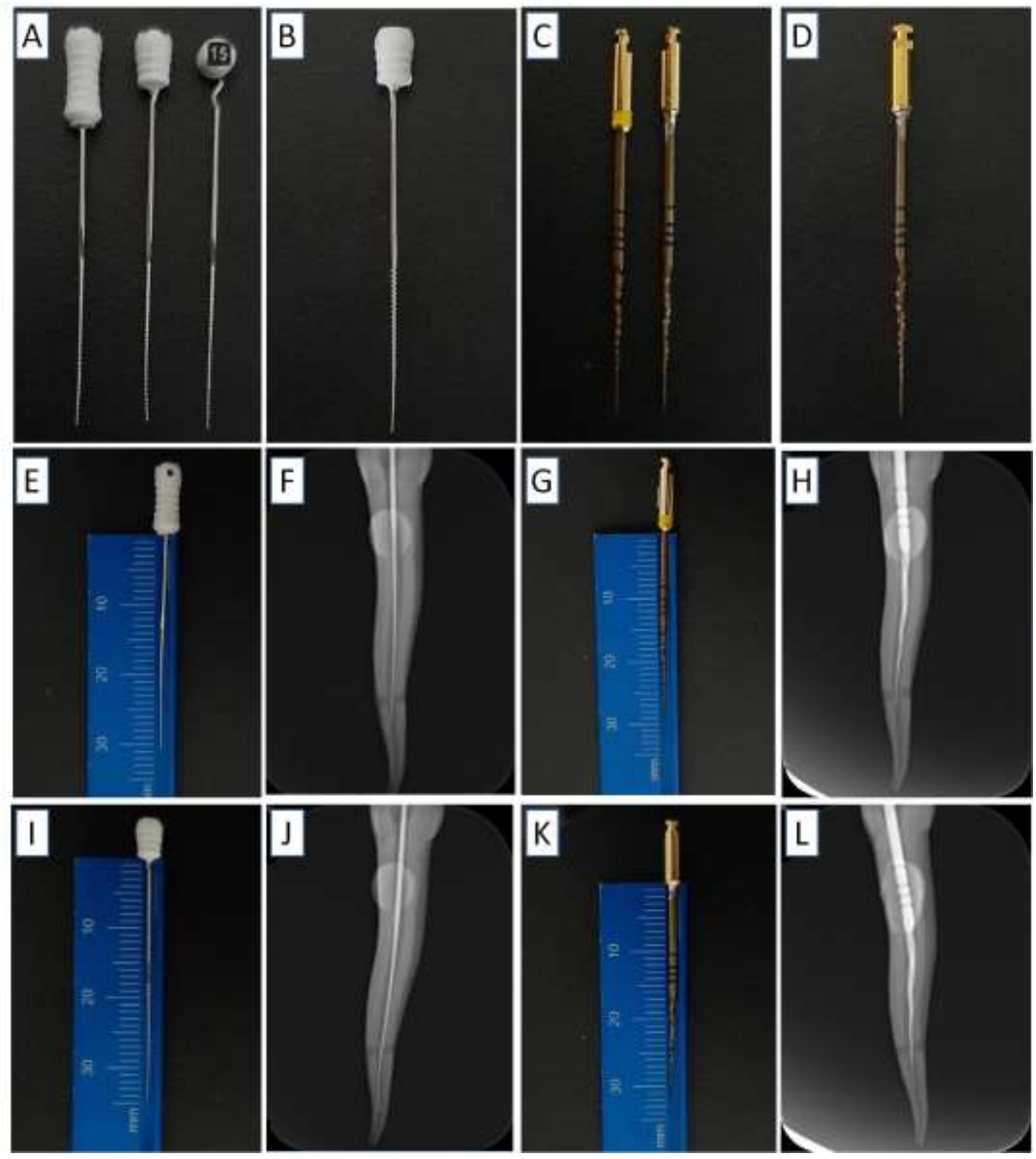

Fonte: Autores.

\section{Changing the reference point of the endodontic instrument}

The traditional reference point of the endodontic instrument is the incisal limit (Figure 3A). Adopting the cervical limit of the access cavity as reference may allow a longer working length - WL (Figure 3B). This alteration worked with the manual file, while the head of the contra angle handpiece did not allow using this conformation with rotary file (Figures $3 \mathrm{C}$ 3F). Radiographic measurement showed that this changing allowed to reach the canal length using hand file (Figure $3 \mathrm{E}$ ). 
Figure 3. (A) Traditional reference point of the endodontic instrument. (B) Reference point modified to the cervical limit of the access cavity. (C) Hand file in position. (D) Contra angle handpiece limitation. (E) Radiographic measurement reaching the WL using hand file, $(F)$ and not reaching the WL using rotary file.
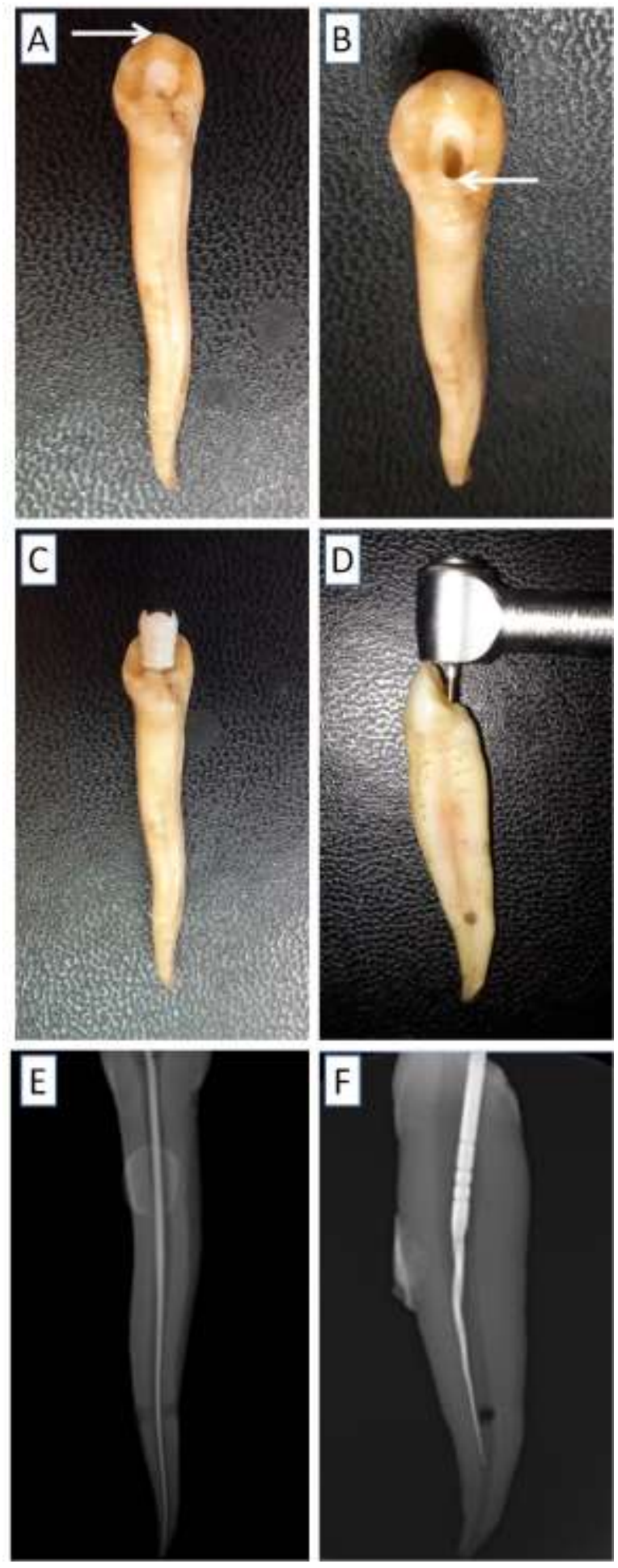

Fonte: Autores (2021).

\section{Discussion}

The aim of this study was to report technical procedures of preparation of long root canal treatment, in this case, a maxillary canine with $39.59 \mathrm{~mm}$. 
About $13.21 \%$ of the maxillary canine are longer than $31 \mathrm{~mm}$, most with curvatures $(81.08 \%)$ (Zmener, Macchi, \& Banegas, 2015). Thus, the professionals should be ready to deal with such cases in the clinical practice, once the industry not offers options of endodontic instruments.

Few studies about root canal treatment of long teeth are reported in the literature, ranging from 32 to $42 \mathrm{~mm}$ of WL (Al-Dahman et al., 2017; Barletta et al., 2010; Bellizzi, 1982; Booth, 1988; Cardoso et al., 2019; Hussain \& Awooda, 2020; Maden et al., 2010; Pace et al., 2011; Vargo \& Hartwell, 1992; Venokur \& Fink, 1976; Zmener, 2003). However, some authors revealed the existence of extremely long teeth, with maxillary canines ranging from 41 to 52 mm (Booth, 1988; Hayward, 1980; Marashi \& Gorlin, 1990; Wilkie \& Chambers, 1990). Venokur and Fink (1976) were the first authors that reported root canal treatment of long teeth (41-42 $\mathrm{mm})$, but without detailing.

Regarding the strategies of treating long teeth, four strategies were found in order to compensate the limitations of the endodontic instruments: endodontic instrument adaptation (Bellizzi, 1982; Cardoso et al., 2019; Hussain \& Awooda, 2020), changing the reference edge of the endodontic instrument (Al-Dahman et al., 2017; Barletta et al., 2010; Vargo \& Hartwell, 1992), wearing the crown by drill in order to reach the ideal WL, and using veterinary files.

The four strategies discussed can be used alone or in association, depending on the difficulties of the cases. In this report, the endodontic instrument adaptation and changing the reference point of the instrument were the procedures adopted.

The endodontic instrument adaptation is based on cutting about $3 \mathrm{~mm}$ from the plastic part of the cable with a diamond tip in order to gain additional mm during the root canal preparation to reach the WL. Cardoso et al. (2019) highlight that in this technique the amplitude of the rotational movement, used in hand files, as well as the application of the apical force during the preparation must be reduced. Hussain and Awooda (2020) suggest to remove all the cable heating it over flame and when it became soft before melting it is pulled away by dental tweezer. According the authors, the hand files are grasped by a tweezer in an inverted pen grasp and the canal is biomechanically prepared by push-pull movement.

Barletta et al. (2010) described an endodontic treatment of a maxillary canine measuring $36 \mathrm{~mm}$. The authors changed the reference point of the endodontic instrument from incisal to cervical limit. Root canal preparation was carried out using Kfiles, obtaining a distance of $1.5 \mathrm{~mm}$ between the file tip and the radiographic apex (34.5 mm of WL). By using the palatal reference point, the overall WL could be reduced by $12 \mathrm{~mm}$ and the $31 \mathrm{~mm}$ length files would be long enough for the appropriate cleansing and shaping of the root canal system (Vargo \& Hartwell, 1992). If necessary, the endodontist could wear the crown by drill in order to reach the ideal WL. This technique is indicated only for small adjustments, since it can cause crown damaging and weakening.

Changing the reference point of the endodontic instrument maybe be safer because the physical characteristics of the endodontic instrument are not modified. In addition, the length gain appears to be greater, as reported by Vargo and Hartwell (1992), reaching $12 \mathrm{~mm}$. Moreover, the clinical techniques can be employed together. Another option is to use veterinary files, such as Vetinox ${ }^{\circledR}$ Hedstroem File (Dentsply Maillefer, Ballaigues, Switzerland), that presents 40 and $60 \mathrm{~mm}$ of length, and could be used as an alternative for these cases. Maden et al. (2010) presented a case of a girl with a mandibular canine (47.5 $\mathrm{mm}$ ) with two canals, with 37.5 and $38.5 \mathrm{~mm}$ of WL, respectively, treated using veterinary files. Also, Pace et al. (2011) performed root canal retreatment of mandibular canine and mandibular first premolar using these files.

Wearing the crown by drill in order to reach the ideal WL is indicated only for small adjustments, since it can cause crown damaging and weakening. This strategy was not used here because the WL was reached using the previously techniques. 


\section{Conclusion}

Root canal treatment in patients with extremely long teeth is challenging. This study showed that these cases can be successfully instrumented endodontically if utilized the described clinical techniques. Professionals should be ready to deal with long teeth in the clinical practice and the industry shall consider to include more options of endodontic instruments. A possible limitation of this study may be related to the fact that one of the adaptations was not made, that includes the use of veterinary files.

\section{References}

Al-Dahman, Y. H., Al-Hawwas, A. Y., \& Al-Jebaly, A. S. (2017). Root canal treatment of a 32-mm length maxillary canine - a case report. International Journal of Contemporary Medical Research, 4(11), 2297-2299.

Al-Obaida M. A. (2020). Rare case of nonsyndromic generalized radiculomegaly with a literature review. Case Reports in Dentistry, $2020,3974829$. http://doi.org/10.1155/2020/3974829.

Barletta, F. B., Grecca, F. S., Wagner, M. H., Ferreira, R., \& Lopez, F. U. (2010). Endodontic treatment of a 36-mm long upper cuspid: clinical case report. Revista Odonto Ciência, 25(4), 412-416. https://doi.org/10.1590/S1980-65232010000400017

Bellizzi, R. (1982). Endodontic therapy associated with a case of cuspid gigantism. Oral Surgery, Oral Medicine, and Oral Pathology, 53(2), 199-202. https://doi.org/10.1016/0030-4220(82)90287-0

Bolla, N., \& Kavuri, S. R. (2011). Maxillary canine with two root canals. Journal of Conservative Dentistry, 14(1): 80-82. https://doi.org/10.4103/09720707.80726

Booth, J. M. The longest tooth? (1988). Australian Endodontic Newsletter, 13(2), 17. https://doi.org/10.1111/J.1747-4477.1987.TB00211.X

Burns, R. C., \& Buchanan, L. S. (1994). Tooth morphology and access openings. In: Cohen, S., \& Burns, R. C. (Eds). Pathways of the Pulp (pp. 128-178). Boston, MA: Mosby.

Cardoso, R. M., Vieira, T. M., Limoeiro, A. G., Bastos, H., Tomazinho, L. F., \& Albuquerque, D. S. (2019). An alternative technique to Endodontic treatment for long teeth: A case report. Journal of Surgical and Clinical Dentistry, 17(1). 8-10. https://www.mastereditora.com.br/periodico/20190310_114148.pdf

Gorlin, R. J., Marashi, A. H., \& Obwegeser, H. L. (1996). Oculo-facio-cardio-dental (OFCD) syndrome. American Journal of Medical Genetics, 63(1): 290292. https://doi.org/10.1002/(SICI)1096-8628(19960503)63:1<290::AID-AJMG47>3.0.CO;2-G'

Hayward, J. R. (1980). Cuspid gigantism. Oral Surgery, Oral Medicine, and Oral Pathology, 49(6), 500-501. https://doi.org/1010.1016/0030-4220(80)900705

Hussain, S.E., \& Awooda, E. M. (2020). Root canal treatment for a lengthy maxillary canine of 37 mm. Case Report. Journal of Case Reports in Dental Medicine, 2(2), 36-39. https://doi.org/10.20956/jcrdm.v2i2.108

Kato, J., Kushima, K., \& Kushima, F. (2018). New radiological findings and radiculomegaly in oculofaciocardiodental syndrome with a novel BCOR mutation: A case report. Medicine (Baltimore), 97(49), e13444. https://doi.org/10.1097/MD.0000000000013444

Maden, M., Savgat, A., \& Görgül, G. (2010). Radiculomegaly of permanent canines: report of endodontic treatment in OFCD syndrome. International Endodontic Journal, 43(12), 1152-1161. https://doi.org/ 10.1111/j.1365-2591.2010.01788.x

Marashi, A. H., \& Gorlin, R. J. (1990). Radiculomegaly of canines and congenital cataracts - a syndrome? Oral Surgery, Oral Medicine, and Oral Pathology, 70(6): 802-803. https://doi.org/10.1016/0030-4220(90)90025-n

Pace, R., Giuliani, V., \& Pagavino, G. (2011). Endodontic management in oculo-facio-cardio-dental syndrome: a case report. Journal of Endodontics, 37(4), 558-561. https://doi.org/10.1016/j.joen.2010.12.015

Pace, R., Giuliani, V., \& Pagavino, G. (2011). Endodontic management in oculo-facio-cardio-dental syndrome: a case report. Journal of Endodontics, 37(4), 558-561. https://doi.org/10.1016/j.joen.2010.12.015

Pécora, J. D., Sousa Neto, M. D., \& Saquy, P. C. (1993). Internal anatomy, direction and number of roots and size of human mandibular canines. Brazilian Dental Journal, 4(1), 53-57. https://www.forp.usp.br/bdj/bdj4(1)/trab0841.pdf

Sajnani, A. K. (2015). Permanent maxillary canines - review of eruption pattern and local etiological factors leading to impaction. Journal of Investigative and Clinical Dentistry, 6(1), 1-7. https://doi.org/10.1111/jicd.12067

Smith, M. H., Cohen, D. M., Bhattacharyya, I., Islam, N. M., \& Kashtwari, D. (2018). Radiculomegaly: a case report of this rare dental finding with review of the associated oculo-facio-cardio-dental syndrome. Oral Surgery, Oral Medicine, Oral Pathology and Oral Radioogy, 126(4), e220-e227. https://doi.org/10.1016/j.oooo.2018.02.011

Somalinga Amardeep, N., Raghu, S., \& Natanasabapathy, V. (2014). Root canal morphology of permanent maxillary and mandibular canines in Indian population using cone beam computed tomography. Anatomy Research International, 2014, 731859. https://doi.org/10.1155/2014/731859 
Research, Society and Development, v. 10, n. 8, e39710817416, 2021

(CC BY 4.0) | ISSN 2525-3409 | DOI: htttp://dx.doi.org/10.33448/rsd-v10i8.17416

Vargo, J. W., \& Hartwell, G. R. (1992). Modified endodontics for lengthy canals. Journal of Endodontics, 18(10), 512-514. https://doi.org/ 10.1016/S00992399(06)81354-3

Venokur, P. C., \& Fink, H. D. (1976). Maxillary canine of unusual length. Oral Surgery, Oral Medicine, and Oral Pathology, $42(1), 137$. https://doi.org/10.1016/0030-4220(76)90042-6

Vertucci, F. J. (2005). Root canal morphology and its relationship to endodontic procedures. Endodontic Topics, 10(1), 3-29. https://doi.org/10.1111/j.16011546.2005.00129.x

Wilkie, G. J., \& Chambers, I. G. (1990). A very large maxillary cuspid. Oral Surgery, Oral Medicine, and Oral Pathology, 1990; 70(2): 159-160. https://doi.org/10.1016/0030-4220(90)90110-e

Zmener, O. (2003). Caninos extra largos: revisión de la literatura y presentación de un caso. Endodoncia, 21, 151-153.

Zmener, O., Macchi, R. L., \& Banegas, G. (2005). Caninos extralargos: análisis de su frecuencia e inconvenientes para el tratamiento endodóntico. Revista de la Asociación Odontológica Argentina, 93(1), 13-16. 